\title{
Pathogenesis of Mucosal Injury in the Blind Loop
}

\section{Syndrome}

\author{
BRUSH BORDER ENZYME ACTIVITY AND GLYCOPROTEIN DEGRADATION
}

\author{
anita Jonas, Peter R. Flanagan, and Gordon G. Forstner, \\ Gastrointestinal Unit and Research Institute, The Hospital for Sick \\ Children, Toronto, Canada
}

A B S T R A C T The effect of intestinal bacterial overgrowth on brush border hydrolases and brush border glycoproteins was studied in nonoperated control rats, control rats with surgically introduced jejunal selfemptying blind loops, and rats with surgically introduced jejunal self-filling blind loops. Data were analyzed from blind loop segments, segments above and below the blind loops, and three corresponding segments in the nonoperated controls. Rats with selffilling blind loops had significantly greater fat excretion than controls and exhibited significantly lower conjugated:free bile salt ratios in all three segments. Maltase, sucrase, and lactase activities were significantly reduced in homogenates and isolated brush borders from the self-filling blind loop, but alkaline phosphatase was not affected. The relative degradation rate of homogenate and brush border glycoproteins was assessed by a double-isotope technique involving the injection of $\mathrm{D}-\left[6-{ }^{3} \mathrm{H}\right]$ glucosamine $3 \mathrm{~h}$ and $\mathrm{D}$ [U-14 $\mathrm{C}$ ]glucosamine $19 \mathrm{~h}$ before sacrifice, and recorded as a ${ }^{3} \mathrm{H}:{ }^{14} \mathrm{C}$ ratio. The relative degradation rate in both homogenate and brush border fractions was significantly greater in most segments from rats with selffilling blind loops. In the upper and blind loop segments from rats with self-filling blind loops, the ${ }^{3} \mathrm{H}:{ }^{14} \mathrm{C}$ ratios were higher in the brush border membrane than in the corresponding homogenates, indicating that the increased rates of degradation primarily involve membrane glycoproteins. Incorporation of D- $\left[6-{ }^{3} \mathrm{H}\right]$ glucosamine by brush border glycoproteins was not reduced in rats with self-filling blind loops, suggesting that glycoprotein synthesis was not affected. Polyacrylamide gel electrophoresis of brush border glycoproteins from the contaminated segments indicated that the large molecular weight glycoproteins,

Received for publication 28 February 1977 and in revised form 20 June 1977. which include many of the surface hydrolases, were degraded most rapidly. Brush border maltase, isolated by immunoprecipitation, had ${ }^{3} \mathrm{H}:{ }^{14} \mathrm{C}$ ratios characteristic of the most rapidly degraded glycoproteins. The results indicate that bacteria enhance the destruction of intestinal surface glycoproteins including disaccharidases. Since alkaline phosphatase, a glycoprotein, is not affected, the destruction is selective and presumably involves only the most exposed membrane components.

\section{INTRODUCTION}

Bacterial overgrowth is associated with disaccharidase deficiency in both man (1) and experimental animals $(2-4)$. The sequence of events which produces this change is not completely understood. Since disaccharidases are attached to the surface brush border membrane of the mature villus epithelial cells of the intestine (5), total tissue activity depends not only on the density of enzyme molecules per unit area of brush border membrane, but on the total surface area of the mature cells to which the enzymes are bound. Disaccharidase levels are therefore influenced not only by factors which affect their synthetic and degradative rates, but by factors which influence the turnover of plasma membrane constituents and enterocytes as well.

As a result of their location, disaccharidases appear to be vulnerable to removal by agents which release them from isolated membranes in vitro. For example, sodium deoxycholate, a by-product of the bacterial deconjugation of bile salts (6), leaches disaccharidases from isolated brush border membranes (7) and has also been shown to lower disaccharidase levels in animals when ingested in excess (8). Both sucrase and maltase are rapidly removed from brush border membranes in vitro by papain $(5,9)$, and this susceptibility appears 
to extend to pancreatic proteases under physiological conditions as well (10). These facts suggest that bacterial by-products or proteases could cause disaccharidase deficiency by releasing enzymes from the exposed brush border membrane surface. On the other hand, the electron microscope has revealed a number of ultrastructural abnormalities in epithelial cells exposed to bacterial overgrowth (11-15) which suggest that destruction of the entire surface membrane or impaired synthesis of membrane components could account for diminished activity. It is also recognized that cell turnover is increased in conventional as compared with germfree animals (16), and such a trend, if extended to bacterial overgrowth syndromes, might greatly reduce the number of mature cells in a given area of intestine.

To investigate the importance of surface damage and increased loss of surface disaccharidases in bacterial contamination syndromes, we have studied the activity of four hydrolases-maltase, sucrase, lactase, and alkaline phosphatase - in insolated brush border membranes as well as in intestinal mucosal homogenates from rats with surgically prepared self-filling blind loops (SFBL).1 In addition, since disaccharidases are glycoproteins which form part of the glycocalyx (17), we have estimated the degradation rate of membrane-bound glycoproteins, using a radioactively labeled glycoprotein precursor. Our studies indicate that disaccharidase deficiency is associated with greatly increased loss of surface glycoproteins including the ectoenzymes, and that this loss occurs in a selective manner affecting alkaline phosphatase and the brush border membrane to a lesser degree.

\section{METHODS}

Animals. Male Wistar rats (Woodland, Guelph, Ontario) weighing approximately $250 \mathrm{~g}$ were housed in individual wire-bottom cages and fed a synthetic diet consisting of $25 \%$ casein hydrolysate (Grand Island Biological Co., Grand Island, N. Y.) $25 \%$ starch, $35 \%$ sucrose, $10 \%$ corn oil, 4\% salt mixture W (ICN Nutritional Biochemicals Div., International Chemical \& Nuclear Corp., Cleveland, Ohio), $2 \%$ vitamin diet fortif (ICN Nutritional Biochemicals Div.), and water ad libitum.

Body weight and food intake were recorded on a weekly basis. The results from three groups of animals are reported in this paper: six rats with a SFBL constructed $15 \mathrm{~cm}$ distal to the ligament of Treitz as described by Cameron (18) and two control groups consisting of five rats with self-emptying blind loops (SEBLs) constructed at the same level and five normal, nonoperated rats. Results obtained with two additional groups, rats with internal pancreato-biliary diversion to the terminal ileum and rats with pancreato-biliary diversion plus a SFBL, will be the subject of a succeeding paper.

\footnotetext{
${ }^{1}$ Abbreviations used in this paper: PBS, phosphate-buffered saline; SDS, sodium dodecyl sulfate; SEBL, self-emptying blind loop; SFBL, self-filling blind loop.
}

The effectiveness of the bacterial overgrowth syndrome was assessed by growth curves, fecal fat balances determined 7 wk postoperatively in a 3-day stool collection using tail cups to prevent coprophagy, and measurement of the luminal bile salt pattern. The stool fat was determined by the method of van der Kamer et al. (19). Luminal contents were collected by flushing each intestinal segment with $154 \mathrm{mM} \mathrm{NaCl}$. Bile salts were determined by semiquantitative thin-layer chromatography using a modification of the method described by Hofmann (20). The specimens were spotted on silicacoated plates (Mondray Ltd., Montreal, Quebec), and free and conjugated bile salts were extracted by solvents described by Sudarah et al. (21) and Kottke et al. (22). Plates were stained with $15 \%$ phosphomolybdic acid in ethanol and the spot size compared with standard bile salt (General Biochemical Div. of The Mogul Corp., Chagrin Falls, Ohio). Results wer expressed as conjugated:free bile salt ratios.

Preparation of mucosal homogenates and brush border membranes. Rats were anesthetized with ether $8 \mathrm{wk}$ postoperatively. The entire length of the small gut from the pylorus to the ileo-cecal sphincter was removed and divided into three segments: the blind loop, the upper segment proximal to the blind loop, and the distal segment. In nonoperated animals, the intestine was divided into upper, middle, and distal segments corresponding to those of the animals with blind loops. Each of the intestinal segments was rinsed with approximately $20.0 \mathrm{ml}$ of ice-cold $154 \mathrm{mM}$ $\mathrm{NaCl}$, and the initial $3 \mathrm{ml}$ was used for bile salt determinations. Segments were then everted and the mucosa removed by scraping with glass slides. The scrapings were homogenized for $20 \mathrm{~s}$ in a Waring Blendor in $100 \mathrm{vol}$ of $5.0 \mathrm{mM}$ EDTA (pH 7.4). $10 \mathrm{ml}$ of the mucosal homogenate was reserved and the remainder used for brush border membrane preparation as described previously (23).

Assays. Disaccharidases and alkaline phosphatase were determined on mucosal homogenates and brush border membranes from each segment. Maltase, sucrase, and lactase were determined as described by Dahlquist (24). Alkaline phosphatase was assayed using $\boldsymbol{p}$-nitrophenyl phosphate as described previously (23). One unit of enzyme activity is defined as that amount required to hydrolyze $1 \mu \mathrm{mol}$ of substrate per minute. Protein was determined by the method of Lowry et al. (25). Hexosamine was determined as described by Allison and Smith (26) after hydrolysis of acidprecipitated, lipid-free tissues in $4.0 \mathrm{~N} \mathrm{HCl} \mathrm{(17).} \mathrm{Sugar} \mathrm{analy-}$ sis was performed by gas-liquid chromatography (GLC) after methanolysis (27).

Glycoprotein degradation. Relative degradation ratios were determined using a double-isotope labeling method employing $\mathrm{D}-\left[6{ }^{3} \mathrm{H}\right]$ glucosamine and $\mathrm{D}-\left[\mathrm{U}-{ }^{14} \mathrm{C}\right]$ glucosamine as described previously (28). Unfasted rats were injected i.p. $19 \mathrm{~h}$ before sacrifice $\left(5: 00\right.$ p.m.) with $10 \mu \mathrm{Ci} \mathrm{D}-\left[\mathrm{U}-{ }^{14} \mathrm{C}\right] \mathrm{glu}$ cosamine (New England Nuclear, Boston, Mass., 10.13 Ci/ $\mathrm{mmol}$ ) in $0.5 \mathrm{ml} 154 \mathrm{mM} \mathrm{NaCl}$. Food was subsequently withheld, but rats were allowed free access to water until sacri-

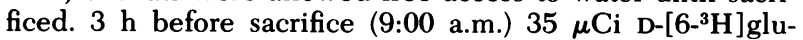
cosamine (New England Nuclear, $228.0 \mathrm{Ci} / \mathrm{mmol}$ ) in $0.35 \mathrm{ml}$ $154 \mathrm{mM} \mathrm{NaCl}$ was injected intraperitoneally. In preliminary experiments, both isotopes were injected simultaneously $3 \mathrm{~h}$ before sacrifice into one rat with SFBL and one nonoperated control rat. In each case the ${ }^{3} \mathrm{H}:{ }^{14} \mathrm{C}$ ratios in homogenates and brush borders were virtually identical, ranging between 3.0 and 3.2. In order to exclude the possibility that relative degradation ratios might be affected by major differences in the rate of incorporation at the time of administration of the first isotope (5:00 p.m.), three rats with SFBL and three nonoperated control rats were injected with $35 \mu \mathrm{Ci} \mathrm{D}-\left[6{ }^{3} \mathrm{H}\right]$ glucosamine at 5:00 p.m. and sacrificed $3 \mathrm{~h}$ 
later at 8:00 p.m. Mean brush border incorporation was $35.8 \times 10^{3} \mathrm{dpm} / \mathrm{mg}$ protein in the SFBL rats (range 32.8$38.4 \times 10^{3}$ ) and $32.3 \times 10^{3} \mathrm{dpm} / \mathrm{mg}$ protein (range 29.0$\left.34.0 \times 10^{3}\right)$ in the middle segment of the nonoperated control rats. These results were not significantly different from the 3-h incorporation of $\mathrm{D}-\left[6-{ }^{3} \mathrm{H}\right]$ glucosamine injected at 9:00 a.m. (Table VI).

Determination of incorporated radioactivity. Suitable aliquots (0.3-0.6 ml) of mucosal homogenates, brush border membranes (in EDTA), and hexosamine (in water) were added to $15.0 \mathrm{ml}$ of Bray's solution (28). Vials were counted in an Isocap 200 scintillation counter (Packard Instrument Co., Inc., Downers Grove, Ill.) calibrated for ${ }^{3} \mathrm{H}$ and ${ }^{14} \mathrm{C}$. Quenching was determined and corrected for by a channels ratio method.

SDS-polyacrylamide gel electrophoresis. Brush border fractions were solubilized in $2 \%$ SDS after the addition of $3.0 \mathrm{mg}$ of $\mathrm{Na}_{2} \mathrm{CO}_{3}$ per $\mathrm{mg}$ protein, without addition of sulfhydryl reagents, and polyacrylamide disc gels were prepared as described previously (29). Staining with $0.25 \%$ Coomassie Blue, slicing, and determination of radioactivity per slice of gel were performed as described elsewhere (28).

Immunoprecipitation of maltase-glucoamylase. Pure rat maltase-glucoamylase $(70 \mathrm{U} / \mathrm{mg}$ protein) was prepared by a method similar to that described by Kelly and Alpers for the human enzyme (30), and an antibody to it was raised in rabbits. The antibody was further purified by precipitation of antiserum with $50 \%$ ammonium sulfate and suspended in phosphate-buffered saline (PBS) to give $15.0 \mathrm{mg}$ of protein per $\mathrm{ml}$. The antibody gave a single precipitin line against supernatants from intestinal homogenate and purified maltase-glucoamylase and gave no reaction with purified rat intestinal sucrase-isomaltase. Maltase-glucoamylase was solubilized by treating brush borders with papain (29); the papainsolubilized material was dialyzed against two changes of icecold distilled water for $48 \mathrm{~h}$, lyophilized, and suspended in PBS, to yield $5 \mathrm{U}$ of maltase per $0.1 \mathrm{ml}$ of solution.

For purposes of immunoprecipitation, the following reagents were mixed: $3.0 \mathrm{U}$ of maltase, $30 \mu \mathrm{g}$ of maltase-glucoamylase antibody, $10 \mu \mathrm{l}$ of normal rabbit serum, $200 \mu \mathrm{l}$ of $20 \%$ Triton X-100 (Rohm \& Haas Co., Philadelphia, Pa.); the reagents were added in that order and made up to $1.7 \mathrm{ml}$ with PBS. After $1 \mathrm{~h}$ at room temperature, $100 \mu \mathrm{l}$ of sheep anti-rabbit IgG was added and the tubes mixed and held at $4^{\circ} \mathrm{C}$ overnight. After centrifugation at $2,000 \mathrm{~g}$ for $30 \mathrm{~min}$, the supernatant was decanted and the precipitate washed twice with $1 \%$ Triton X-100 in PBS. Maltase activity and disintegrations per minute were measured in the precipitate and supernatant. $85 \%$ of the maltase activity in the papainsoluble fraction was precipitated with antibody, and less than $1 \%$ in control tubes without antibody. Background radioactivity in control tubes was less than $7 \%$ of antibody-containing tubes. Sucrase, lactase, alkaline phosphatase, and $\beta$-naphthylamidase were not precipitated. $100 \%$ of maltase activity was recovered in the combined supernatant and pellet fractions, indicating that the antibody did not inhibit enzyme activity while combining with maltase-glucoamylase. Maltase disintegrations per minute per milligram of protein were calculated from the maltase activity of the precipitate assuming a specific activity of $60 \mathrm{U} / \mathrm{mg}$ protein.

Histology. Sections from SFBL, SEBL, and jejunum of normal rats were fixed in Bouin's solution, transferred to $95 \%$ ethanol, oriented at right angles to the long axis of the intestine, and cut into 5- $\mu \mathrm{m}$ sections. These were stained with hematoxylin-eosin and periodic acid-Schiff (PAS)-hematoxylin-saffron. A calibrated eyepiece was used to measure villus height (from tip of villus to opening of crypt), crypt depth (from opening of crypt to its base), and whole intestinal wall thickness (serosa to tip of villus. At least 10 well-oriented villi were examined in each section.

For electron microscopy studies, mucosa were fixed in $3 \%$ glutaraldehyde in $0.1 \mathrm{M}$ phosphate buffer, rinsed in the same buffer, postfixed in $1 \%$ osmium tetroxide in $0.38 \mathrm{M}$ Veronal

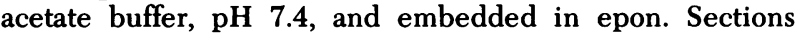
stained with uranyl acetate and lead citrate were examined in a Philips EM 200 electron microscope (Philips Electronic Instruments, Inc., Mount Vernon, N. Y.).

\section{RESULTS}

Rats with SFBL were assessed and compared with nonoperated and SEBL control rats, with respect to growth rate, intestinal fat absorption, bile salt deconjugation, bacterial cultures of SFBL contents, and the gross and microscopic appearance of the blind loop segment. All parameters were consistent with a marked degree of bacterial overgrowth. Although rats in all groups grew steadily throughout the study and remained healthy, SFBL rats grew at a slower rate and weighed significantly less than controls at the time of sacrifice (Table I). SFBL rats also showed significantly greater fat excretion than controls (Table I). An excess of unconjugated bile salts, resulting in a very low conjugated:unconjugated bile salt ratio, was seen in all three intestinal segments from SFBL rats (Table I), whereas conjugated:unconjugated bile salt ratios were high in all segments from rats in the two control groups. Although quantitation was not attempted, cultures of the con-

TABLE I

Comparison of Body Weight, Fat Excretion, and Luminal Conjugated:Free Bile Salt Ratios in Rats with SFBL, and Control Rats (Nonoperated and SEBL)

\begin{tabular}{lccc}
\hline & $\begin{array}{c}\text { SFBL rats } \\
(6)\end{array}$ & $\begin{array}{c}\text { Nonoperated } \\
\text { rats (5) }\end{array}$ & $\begin{array}{c}\text { SEBL rats } \\
(5)\end{array}$ \\
\hline Body wt, g & $380 \pm 11.2$ & $453 \pm 17.6^{*}$ & $424 \pm 16.6$ \\
$\begin{array}{l}\text { Stool fat, \% of intake } \\
\text { Conjugated:free bile } \\
\text { salt ratio }\end{array}$ & $6.9 \pm 1.3$ & $2.1 \pm 0.3 \ddagger$ & $2.7 \pm 0.1^{*}$ \\
$\quad \begin{array}{l}\text { Upper segment } \\
\text { Middle segment } \\
\text { (blind loop) }\end{array}$ & $0.8 \pm 0.3$ & $9.2 \pm 2.0^{*}$ & $16.9 \pm 4.9 \S$ \\
$\quad 0.3 \pm 0.1$ & $7.5 \pm 1.8^{*}$ & $11.1 \pm 2.1 \ddagger$ \\
Lower segment & $0.4 \pm 0.2$ & $2.2 \pm 0.3 \ddagger$ & $6.2 \pm 1.8 \S$ \\
\hline
\end{tabular}

All rats weighed approximately $250 \mathrm{~g}$ at operation. The body weights in the table were taken at the start of the 8th postoperative week. Stool fat excretion was determined during the 7th postoperative week. Stool fat and bile salt ratios were determined as in Methods. The number of rats in each group is given in parentheses. Results are expressed as the mean $\pm S E$. Probability for values (Student $t$ test for unpaired data) for comparison of nonoperated and SEBL control rats with SFBL rats are:

$* P<0.01$.

$\ddagger P<0.001$.

$\S P<0.05$. 
tents from the SFBL yielded heavy growths of multiple species of anaerobic bacteria including bacteroides, clostridia, and streptococcus faecalis. The SFBL was obviously distended and hyperemic with both muscular and mucosal hypertrophy. Villi and crypts were both elongated, but the villous:crypt ratio (1.9) was less than that of the SEBL (2.2) or the control middle segment from nonoperated rats (3.1). Patchy ultrastructural abnormalities, including swelling and distortion of microvilli, swelling of mitochondria, and irregular swelling and vesiculation of cells similar to those described by Ament et al. (11), Toskes et al. (14), and Gracey et al. (15), were also seen.

Homogenate enzyme specific activities are shown in Fig. 1. Enzyme activities were higher in the upper and middle segments than in the distal segments in the two control groups, as in previous studies $(31,32$ ). Alkaline phosphatase was most active in the proximal segment, whereas the specific activity of the three disaccharidases was as great, or greater, in the middle segment. In the rats with SFBL, the distribution of disaccharidase activities was quite different, since the blind loop segment, although constructed from the middle portion of the bowel, was less active than either lower or upper segment. Similar results have been obtained by others $(2-4)$. The activity in the SFBL was

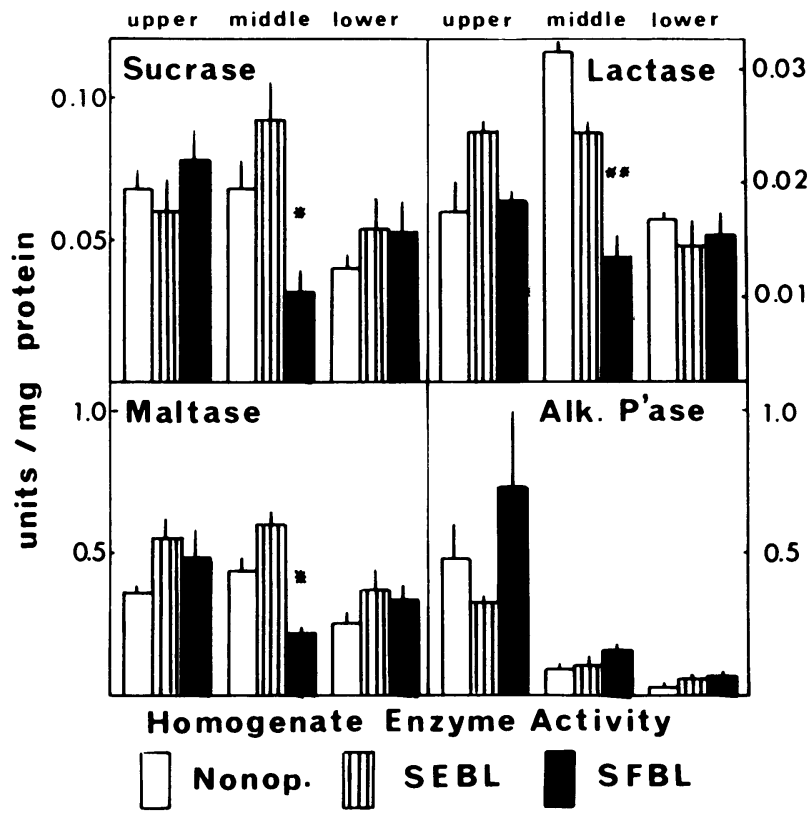

FIGURE 1 Specific activity of mucosal hydrolases from three experimental groups of rats-nonoperated controls (Nonop), control rats with SEBL, and rats with SFBL-in upper, middle, and lower segments as described in methods. Values are means for numbers of rats shown in Table $I \pm S E M$. Significant differences between the mean values in SFBL rats and both nonoperated and SEBL controls are shown by asterisks. ${ }^{*}=P<0.05 ; * *=P<0.01$
TABLE II

Maltase and Sucrase Purification in Brush Border Membranes Prepared from Control Rats and Rats with SFBL

\begin{tabular}{ccc} 
Upper & Middle & \\
segment & $\begin{array}{c}\text { segment or } \\
\text { blind loop }\end{array}$ & $\begin{array}{c}\text { Lower } \\
\text { segment }\end{array}$ \\
\hline
\end{tabular}

Maltase, specific activity in brush border/specific activity in homogenate \pm SEM

Controls

$\begin{array}{llll}\text { Nonoperated (5) } & 23.0 \pm 3.9 & 20.2 \pm 3.5 & 15.8 \pm 3.7\end{array}$

SEBL (5)

$14.8 \pm 2.6 \quad 12.8 \pm 1.2 *+$

$11.0 \pm 1.0 \ddagger$

Experimental

SFBL (6)

$16.6 \pm 1.2 \quad 19.6 \pm 1.1$

$21.4 \pm 2.3$

Sucrase, specific activity in brush border/specific activity in homogenate \pm SEM

Controls

Nonoperated (5) $\quad 17.4 \pm 2.9 \quad 13.3 \pm 3.4 \quad 11.9 \pm 1.0$

SEBL (5)

$16.7 \pm 2.4 \quad 8.0 \pm 1.0$

$10.7 \pm 5.3$

Experimental

SFBL (6)

$12.5 \pm 1.9 \quad 14.7 \pm 3.4$

$15.2 \pm 3.5$

$* P<0.01$, compared with nonoperated group.

$\$ P<0.01$, compared with SFBL rats.

also significantly less than that of the corresponding segments from the controls. In contrast, mucosal alkaline phosphatase appeared to be slightly more active in all three segments from the SFBL animals when compared with the controls.

Brush borders could be prepared from all three groups of animals with approximately the same degree of purity, as judged by the increase in enzyme specific actively compared with the homogenate for sucrase and maltase (Table II). The increase in maltase and sucrase activities was not significantly different for nonoperated and SFBL rats. Purification ratios for maltase and sucrase were smaller in SEBL rats than in either of the other groups. Brush border membranes for rats with SEBLs may therefore have been less pure; however, the specific activities of enzymes in the SEBL brush borders were not significantly different from those of the nonoperated controls (Fig. 2).

The results obtained from isolated brush borders (Fig. 2) are chiefly important because they mirror those of the homogenate so closely. Again, the loss of membrane hydrolase activity was selective. All three disaccharidases were less active in brush borders obtained from the SFBLs, while alkaline phosphatase was not reduced. In general, the brush border results were more dramatic than those of the homogenates, and the differences between the SFBL and the two control segments were accentuated. Fig. 2 also demonstrates that membrane lactase was reduced more than either membrane sucrase or maltase in the SFBL. Purification of brush border lactase was only 3.1-fold in con- 


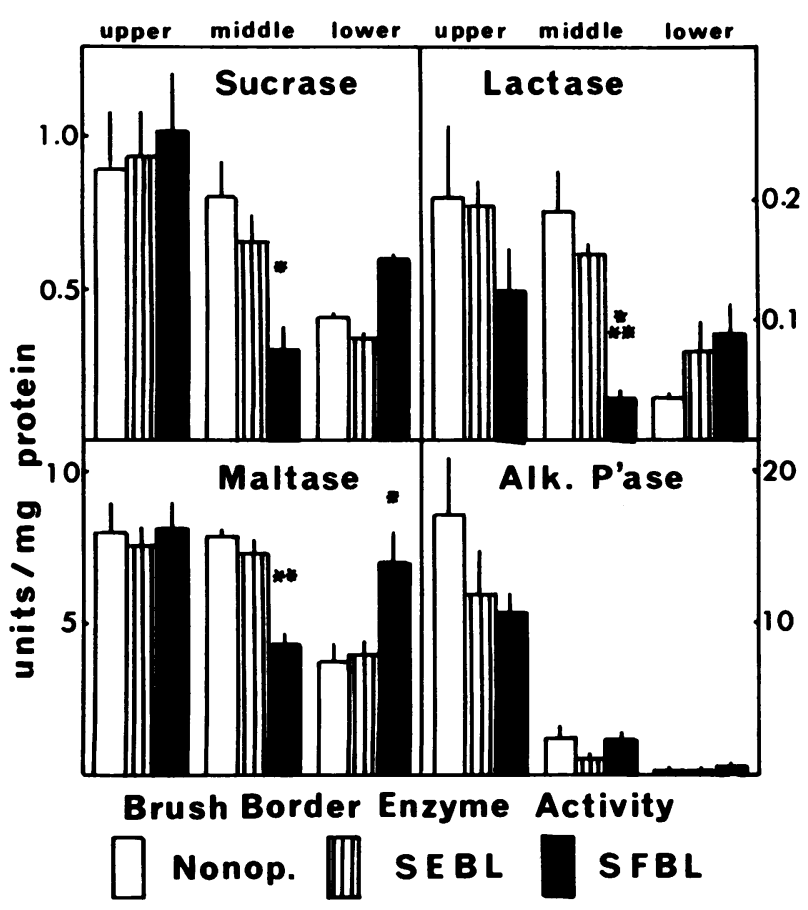

FIgURE 2 Specific activity of brush border hydrolases from the three experimental groups of rats shown in Fig. 1. The significance of the asterisks is same as in Fig. $1^{* * *}=P<0.001$.

trast to 7.1-fold in the nonoperated control rats, even though as noted above the purification of maltase and sucrase was the same in these two groups. Presumably lactase was lost during isolation of the brush border from the SFBL, as if bacterial overgrowth had in some manner destabilized the enzyme.

In contrast to previous studies (2-4) in which short segments of bowel above and below the blind loop were examined, homogenate enzyme activities (Fig. 1) were not significantly different from the controls in the proximal and distal segments from the rats with SFBL. The explanation probably lies in the fact that we examined the total remaining small intestine, and therefore our samples contained considerably more tissue located at a distance from the loop itself. It is noteworthy, however, that the mean specific activity of all four enzymes in the brush border (Fig. 2) was considerably greater in the distal segment of the rats with bacterial overgrowth, although the differences were significant only for maltase. Since these results include a segment close to the BL in which activity may have been depressed, they are impressive and suggest that increased synthesis of new enzymes was stimulated in apparently uninvolved bowel.

Glycoprotein degradation. ${ }^{3} \mathrm{H}:{ }^{14} \mathrm{C}$ ratios for glycoproteins in the homogenates and brush border are shown in Table III. In assessing the relative rates of glycoprotein degradation, the ${ }^{3} \mathrm{H}$ isotope was always given last. Under these circumstances the fastest degradation rates would produce the highest ${ }^{3} \mathrm{H}:{ }^{14} \mathrm{C}$ ratios. In previous experiments in suckling rats (28), homogenate and brush border glycoproteins exhibited similar ${ }^{3} \mathrm{H}:{ }^{14} \mathrm{C}$ ratios, indicating that the overall degradation rate of brush border glycoproteins differed little from that of mucosal glycoproteins. As shown in Table III, ${ }^{3} \mathrm{H}:{ }^{14} \mathrm{C}$ ratios for homogenates and brush border were similar in each segment from the control rats, in basic agreement with the experience in normal suckling rats. There was, however, an interesting tendency for the highest ratios to appear in the fractions from proximal segments. The ${ }^{3} \mathrm{H}:{ }^{14} \mathrm{C}$ ratios obtained in the rats with the SFBL differed from the controls in three fundamental ways: (a) Higher ratios were observed in both homogenates and brush borders from most segments from SFBL rats, indicating that glycoprotein degradation was generally increased. (b) In the upper and $\mathrm{BL}$ segments, the ${ }^{3} \mathrm{H}:{ }^{14} \mathrm{C}$ ratios in the brush border were significantly greater than those of the corresponding homogenates, indicating that the degradation rate for brush border glycoproteins was increased out of proportion to that of the remaining mucosal glycoproteins. (c) Brush border ${ }^{3} \mathrm{H}:{ }^{14} \mathrm{C}$ ratios were highest in the blind loop segment rather than the proximal segment, indicating that brush

\section{TABLE III}

Relative Degradation $\left({ }^{3} \mathrm{H}:{ }^{14} \mathrm{C}\right)$ Ratios in Mucosal and Brush Border Fractions of Control Rats and Rats with SFBL

\begin{tabular}{lccc}
\hline & $\begin{array}{c}\text { Middle } \\
\text { Upper } \\
\text { segment }\end{array}$ & $\begin{array}{c}\text { blind loop } \\
\text { Legmer } \\
\text { segment }\end{array}$ \\
\hline & ${ }^{3} \mathrm{H}:{ }^{14} \mathrm{C} \pm \mathrm{SEM}$ &
\end{tabular}

\begin{tabular}{llll}
$\begin{array}{l}\text { Mucosal homogenate } \\
\text { Controls }\end{array}$ & & & \\
$\quad$ Nonoperated (5) & $11.4 \pm 1.3$ & $8.9 \pm 0.7^{*}$ & $8.0 \pm 0.5^{*}$ \\
SEBL (5) & $10.8 \pm 0.6$ & $8.2 \pm 1.3^{*}$ & $7.2 \pm 1.2^{*}$ \\
$\begin{array}{l}\text { Experimental } \\
\text { SFBL (6) }\end{array}$ & $14.0 \pm 0.7$ & $11.7 \pm 0.6$ & $10.5 \pm 0.8$ \\
$\begin{array}{l}\text { Brush borders } \\
\text { Controls } \\
\quad \text { Nonoperated (5) }\end{array}$ & $11.7 \pm 1.6^{*}$ & $7.5 \pm 0.6 \pm$ & $7.7 \pm 0.8^{*}$ \\
$\quad$ SEBL (5) & $10.4 \pm 0.5^{*}$ & $7.0 \pm 0.6 \ddagger$ & $9.1 \pm 1.9$ \\
$\quad \begin{array}{lll}\text { Experimental } \\
\text { SFBL (6) }\end{array}$ & $21.9 \pm 3.1$ & $27.9 \pm 5.6$ & $16.2 \pm 3.2$ \\
\hline
\end{tabular}

${ }^{3} \mathrm{H}:{ }^{14} \mathrm{C}$ ratios were determined as described in Methods. Brush border ratios were significantly higher than homogenate ratios in the upper and BL segment of the rats with SFBL $(P<0.05)$.

${ }^{*} P<0.05$, for comparison between control fractions and fractions from rats with SFBL.

$\ddagger P<0.01$, for comparison between control fractions and fractions from rats with SFBL. 
TABLE IV

Relative Degradation $\left({ }^{3} \mathrm{H}:{ }^{14} \mathrm{C}\right)$ Ratios in Hexosamine after Hydrolysis of Acid-Precipitable, Lipid-Free Glycoproteins in Brush Border

\begin{tabular}{lll}
\hline \multicolumn{1}{c}{ Experimental group } & ${ }^{3} \mathrm{H}:{ }^{14} \mathrm{C}$ ratios & $P$ \\
\hline Rats with SFBL (6) & $33.0 \pm 5.2$ & \\
Rats with SEBL (5) & $11.3 \pm 2.1$ & $<0.01$ \\
Nonoperated rats (5) & $10.7 \pm 1.2$ & $<0.101$ \\
\hline
\end{tabular}

Brush border glycoprotein was precipitated overnight with $10 \%$ trichloroacetic acid, $1 \%$ phosphotungstic acid, extracted with chloroform-methanol, hydrolyzed in $4.0 \mathrm{~N} \mathrm{HCl}$ and free hexosamine isolated by passage over Dowex 50 as previously described $(17,33)$. Statistical comparison (Student's $t$ test for unpaired data) relate control groups to rats with SFBL. The difference between the control groups was not significant.

border glycoprotein degradation was most rapid in the area of maximal bacterial overgrowth.

The results in Table IV show that the high ${ }^{3} \mathrm{H}:{ }^{14} \mathrm{C}$ ratios are also found in free hexosamine produced by acid hydrolysis of acid-precipitable, lipid-free brush border glycoproteins from the rats with SFBL. These findings exclude the possibility that the ratios are influenced significantly by incorporation into sialic acid and glycolipids.

High ${ }^{3} \mathrm{H}:{ }^{14} \mathrm{C}$ ratios could conceivably be produced by the differential removal of hexosamine by bacterial glycosidases acting on glycoprotein side chains. If this were the case, ${ }^{3} \mathrm{H}:{ }^{14} \mathrm{C}$ ratios would not reflect the rate of degradation of the whole glycoprotein molecule. That such an occurrence is very unlikely is indicated by the results presented in Table V. They show that the carbohydrate composition of brush borders isolated from the SFBL and from the middle segment of the nonoperated control intestine was quite similar. In fact, the three carbohydrates that might be labeled by

\section{TABLE V}

Carbohydrate Composition of Brush Borders Isolated from the Middle Segment of Nonoperated Control Rats and the SFBL

\begin{tabular}{lcr}
\hline & $\begin{array}{c}\text { Nonoperated controls (4) } \\
\text { (middle segment) }\end{array}$ & SFBL (4) \\
\hline Mg/mg proteins \pm SEM \\
Galactosamine & $19.2 \pm 1.7$ & $26.1 \pm 3.1$ \\
Glucosamine & $21.8 \pm 1.5$ & $28.9 \pm 4.6$ \\
Galactose & $12.0 \pm 0.3$ & $12.3 \pm 0.9$ \\
Mannose & $4.8 \pm 0.2$ & $4.1 \pm 0.3$ \\
Fucose & $3.5 \pm 0.2$ & $4.5 \pm 1.1$ \\
$N$-acetyl neuraminic & & \\
$\quad$ acid & $3.8 \pm 1.1$ & $9.5 \pm 2.9$ \\
Glucose & $9.8 \pm 1.5$ & $13.6 \pm 1.3$ \\
Xylose & $0.4 \pm 0.16$ & $0.2 \pm 0.1$ \\
\hline
\end{tabular}

radioactive glucosamine-glucosamine, galactosamine, and $N$-acetyl neuraminic acid-had slightly greater mean concentrations per milligram of protein in brush borders from the SFBL.

Although these studies provide evidence that brush border glycoproteins were more rapidly degraded in SFBL rat intestine, no inference can be drawn with respect to corresponding synthetic rates, since steady-state conditions cannot be assumed. As shown in Table VI, ${ }^{3} \mathrm{H} \mathrm{dpm}$ incorporation at $3 \mathrm{~h}$ was slightly higher in brush borders from rats with SFBL as compared with controls, although the difference was not statistically significant. Since the 3-h time period for $\left[{ }^{3} \mathrm{H}\right]$ glucosamine is close to the point of maximum incorporation of the isotope $(33,34)$, these results imply that glycoprotein synthesis was reasonably well maintained in all segments in SFBL animals, although presumably synthesis was not sufficiently accelerated within the SFBL to compensate completely for enhanced degradation.

In earlier work from this laboratory (26), we have shown in normal brush border that glycoprotein degradation ratios were highest in large molecular weight glycoproteins of the size of sucrase-isomaltase and maltase-glucoamylase. The experiment described in Fig. 3 and Table VII indicates the type of brush border glycoprotein most affected by bacterial contamination. In this experiment a nonoperated control rat was injected with $\left[{ }^{3} \mathrm{H}\right]$ glucosamine i.p. $14 \mathrm{~h}$ before sacrifice to allow ample time for labeling and degradation to occur. At the same time, an SFBL rat was injected with $\left[{ }^{14} \mathrm{C}\right]$ glucosamine. At sacrifice the mucosa from corresponding upper, or blind loop, and middle segments were mixed and brush borders representative of both animals were prepared. Since in the mixed brush borders ${ }^{3} \mathrm{H} \mathrm{dpm}$ reflect the rate of degradation of glycoproteins from the nonoperated rat, while ${ }^{14} \mathrm{C} \mathrm{dpm}$ reflect the degradation rate from the SFBL rat, ${ }^{3} \mathrm{H}:{ }^{14} \mathrm{C}$ ratios in a particular glycoprotein are a direct measure of the difference in the degradation rates of the glyco-

\section{TABLE VI}

${ }^{3} \mathrm{H}$ Radioactivity in Brush Borders $3 \mathrm{~h}$ after Intraperitoneal Injection of Isotope in Intestinal Segments from Rats with SFBL and Control Rats

\begin{tabular}{|c|c|c|c|}
\hline & Upper segment & $\begin{array}{l}\text { Middle segment } \\
\text { or blind loop }\end{array}$ & Lower segment \\
\hline & \multicolumn{3}{|c|}{$d p m{ }^{3} H / m g$ protein $\pm S E M$} \\
\hline Rats with SFBL (6) & $49,479 \pm 9,283$ & $32,487 \pm 4,835$ & $28,198 \pm 7,899$ \\
\hline Rats with SEBL (5) & $41,215 \pm 5,826$ & $23,724 \pm 4,116$ & $16,581 \pm 2,119$ \\
\hline Nonoperated rats (5) & $30,201 \pm 9,805$ & $25,805 \pm 5,932$ & $17,908 \pm 2,080$ \\
\hline
\end{tabular}

$35 \mu \mathrm{Ci} \mathrm{D}-\left[6-{ }^{3} \mathrm{H}\right]$ glucosamine was injected i.p. $3 \mathrm{~h}$ before sacrifice. Brush borders were isolated as described in Methods and radioactivity per milligram of protein determined. The number of samples is shown in parenthesis. Results were corrected for body weight variation, to a constant body weight of $400 \mathrm{~g}$. Values in rats with SFBL were not significantly different from controls (Student's $t$ test). 


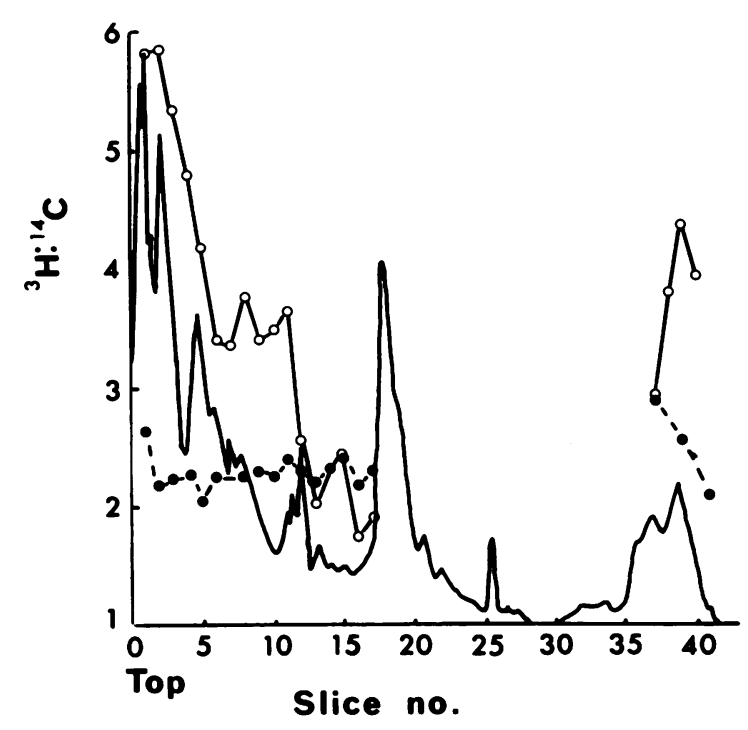

FIGURE $3 \mathrm{H}:{ }^{14} \mathrm{C}$ ratios in slices derived from SDS-polyacrylamide disc gels of mixed brush border fractions solubilized in $2 \%$ SDS. $\bigcirc-O$ : ratios obtained with brush borders prepared from the middle segment from nonoperated rats injected with $70 \mu \mathrm{Ci} \mathrm{D}-\left[6{ }^{3} \mathrm{H}\right]$ glucosamine, and the SFBL of a rat injected with $24 \mu \mathrm{Ci} \mathrm{D}-\left[\mathrm{U}-{ }^{14} \mathrm{C}\right]$ glucosamine $14 \mathrm{~h}$ before sacrifice. prepared from the middle segment of a nonoperated rat injected simultaneously with $35 \mu \mathrm{Ci} \mathrm{D}-\left[6-{ }^{3} \mathrm{H}\right]$ glucosamine and $12 \mu \mathrm{Ci} \mathrm{D}-\left[\mathrm{U}-{ }^{14} \mathrm{C}\right]$ glucosamine $14 \mathrm{~h}$ before sacrifice. The solid line is a densitometer tracing at $600 \mathrm{~nm}$ of a simultaneously run gel of the mixed brush borders stained with Coomassie Blue. Ratios are not shown for those slices in which ${ }^{14} \mathrm{C}$ dpm were less than $1.5 \times$ background.

proteins in the two experimental situations. To indicate ratios to be expected when both isotopes are incorporated and lost simultaneously, a second nonoperated rat received proportionately similar amounts of $\left[{ }^{14} \mathrm{C}\right]$ glucosamine and $\left[{ }^{3} \mathrm{H}\right]$ glucosamine simultaneously $14 \mathrm{~h}$ before sacrifice. This rat is referred to as the control in Fig. 3 and Table VII.

Brush borders were solubilized with $2 \%$ sodium dodecylsulfate (SDS) and applied to polyacrylamide gels. After electrophoresis the gels were sliced serially at 2-mm intervals and analyzed for ${ }^{3} \mathrm{H}$ and ${ }^{14} \mathrm{C} \mathrm{dpm}$. Since both isotopes should disappear at equal rates in all glycoproteins from the control rat, ${ }^{3} \mathrm{H}:{ }^{14} \mathrm{C}$ ratios ought to be identical in all slices from control brush borders. Fig. 3 demonstrates this condition was adequately realized, since the variation from slice to slice, particularly in the upper portion of the gels, was minimal. In contrast, slices from mixed brush borders from the middle and SFBL segments displayed much higher ${ }^{3} \mathrm{H}:{ }^{14} \mathrm{C}$ ratios, and the difference between the ratios was most marked in the macromolecular regions occupied by glycoproteins with a mass in excess of 150,000 daltons (29). This is the area occupied by sucrase, lactase, and maltase, and therefore the results are consistent with accelerated degradation of disaccharidases in the SFBL. Unexpectedly, some material with high ${ }^{3} \mathrm{H}:{ }^{14} \mathrm{C}$ ratios was found traveling close to the tracking dye. This material may represent glycolipid or small molecular weight degradation products, but it was not characterized further.

To determine whether the high ratios were in fact present in a disaccharidase, brush borders were digested with papain and maltase-glucoamylase isolated by immunoprecipitation. ${ }^{3} \mathrm{H}:{ }^{14} \mathrm{C}$ ratios were determined in the immunoprecipitates from upper and middle (SFBL) segments. Table VII compares these values with ratios obtained in the corresponding brush border. As expected in the simultaneously injected control rat, maltase-glucoamylase and brush border ratios were low and similar. Higher ratios were found in both the upper segment and middle (blind loop) segment mixed brush borders, and in each case even higher ratios were obtained in the immunoprecipitated enzyme. These results therefore substantiate the impression gained from SDS-polyacrylamide gel electrophoresis, that the degradation rate of disaccharidases was greatly accelerated in the rats with SFBL.

\section{TABLE VII}

${ }^{3} \mathrm{H}$ and ${ }^{14} \mathrm{C}$ dpm in Brush Border from Mixed Homogenates of Nonoperated and SFBL Rats Injected Independently and in Brush Borders from a Simultaneously Injected Nonoperated Control Rat

\begin{tabular}{lccc}
\hline \multicolumn{1}{c}{ Fraction } & ${ }^{3} \mathrm{H}$ & ${ }^{4} \mathrm{C}$ & ${ }^{3} \mathrm{H}:{ }^{14} \mathrm{C}$ \\
\hline $\begin{array}{l}\text { Mixed upper segment brush } \\
\quad \text { border }\end{array}$ & 27,400 & 7,100 & 3.8 \\
$\begin{array}{l}\text { Mixed BL and middle segment } \\
\quad \text { brush border }\end{array}$ & 18,300 & 4,560 & 4.0 \\
$\begin{array}{l}\text { Control brush border (middle } \\
\quad \text { segment }\end{array}$ & 21,200 & 9,175 & 2.3 \\
$\begin{array}{l}\text { Maltase precipitate, upper } \\
\quad \text { segment }\end{array}$ & 21,950 & 4,980 & 4.4 \\
$\begin{array}{l}\text { Maltase precipitate, blind loop and } \\
\quad \text { middle segment }\end{array}$ & 24,810 & 3,960 & 6.3 \\
$\begin{array}{l}\text { Maltase precipitate, control } \\
\text { Mald }\end{array}$ & 16,710 & 6,970 & 2.4 \\
\hline
\end{tabular}

$14 \mathrm{~h}$ before sacrifice, $70 \mu \mathrm{Ci} \mathrm{D}-\left[6-{ }^{3} \mathrm{H}\right]$ glucosamine was injected intraperitoneally into a nonoperated control rat, and $24 \mu \mathrm{Ci} \mathrm{D}-\left(\mathrm{U}-{ }^{14} \mathrm{C}\right)$ glucosamine into a rat with a SFBL. At death, corresponding segments were removed and combined, and mixed homogenates were prepared from which brush borders were isolated. Incorporated ${ }^{14} \mathrm{C},{ }^{3} \mathrm{H}$, and ${ }^{3} \mathrm{H}:{ }^{14} \mathrm{C}$ ratios were determined in brush border immunoprecipitable maltase as described in Methods. Maltase protein was calculated from activity, assuming a specific activity of $60 \mu / \mathrm{mg}$ protein. Results are compared with control fractions from a nonoperated rat which received $35 \mu \mathrm{Ci} \mathrm{D}-\left[6-{ }^{3} \mathrm{H}\right]$ glucosamine and $12 \mu \mathrm{Ci}$ $\mathrm{D}-\left(\mathrm{U}-{ }^{14} \mathrm{C}\right)$ glucosamine $14 \mathrm{~h}$ before sacrifice. 


\section{DISCUSSION}

Intestinal epithelial damage was thought to play a minor role in the malabsorption imposed by bacterial contamination $(35,36)$ until Gracey et al. (12), Ament et al. (11), and Gianella et al. (13) described ultrastructural enterocyte abnormalities under both clinical (11) and experimental $(12,13)$ conditions. During the same period it became evident that enzymes characteristic of the brush border were depressed within experimental blind loops $(3,4,14)$, and the inference was made that enzyme deficiencies resulted from the damage to the surface microvilli demonstrated by electron microscopy (14). In the present study, we have extended past observations by demonstrating that disaccharidase activities in isolated brush borders are reduced. Since the purification of the brush border membrane from the SFBL was as efficient as that of the controls, these results indicate that the amount of enzyme per unit of brush border membrane was reduced also. Therefore, enzyme deficiency in the affected mucosa cannot be attributed solely to destruction and loss of microvilli, but must be due to independent loss or destruction of the exposed ectoenzymes per se. Indeed, our electron microscopic observations agree with those of Toskes et al. (14), who found that ultrastructural changes were patchy, involving fewer than an estimated $20 \%$ of cells in the villus. These changes, therefore, are not likely to produce sufficient destruction of the plasma membrane surface to account for disaccharidase losses in excess of $50 \%$. The fact that brush border alkaline phosphatase was not affected by bacterial overgrowth, while disaccharidases were, also indicates that selective destruction of enzyme molecules is a more important cause of disaccharidase deficiency than nonspecific loss of plasma membrane.

The stability of brush border alkaline phosphatase shown in the present study may be a relative matter, since in previous experiments $(4,14)$ alkaline phosphatase was depressed by bacterial overgrowth. Nevertheless, alkaline phosphatase appears to be either more deeply situated in the glycocalyx or attached to the membrane by a bond less vulnerable to detergents or proteases. Boedeker et al. (7) have shown, for example, that both a nonionic detergent (Triton X-100) and the anionic detergent, sodium deoxycholate, easily remove disaccharidases but not alkaline phosphatase from the brush border membrane in vitro. In vivo, Gracey et al. (8) have shown that alkaline phosphatase is the first intestinal enzyme to recover from damage produced by feeding deoxycholate. Similarly, alkaline phosphatase is spared by pancreatic proteases, which account for a significant portion of the normal turnover of the brush border disaccharidases (10). The relative stability of the enzyme in the bacterial overgrowth syndrome is therefore not unique and is in fact consistent with current understanding of the behavior of the detergents and proteolytic agents which could be involved in surface destruction.

Our results demonstrate that membrane glycoproteins are degraded more rapidly throughout the bacterially contaminated intestine. That ectoenzymes are prominently involved is indicated by the observation that the glycoproteins with highest ${ }^{3} \mathrm{H}:{ }^{14} \mathrm{C}$ ratios on SDS-polyacrylamide gel electrophoresis occupied the high molecular weight region in which the glycoprotein ectoenzymes are concentrated. In addition, the degradation of immunoprecipitable membrane maltase-glucoamylase was at least as rapid as that of the most rapidly degraded glycoproteins separated by electrophoresis. There can be little doubt, therefore, that disaccharidase destruction is enhanced by bacterial overgrowth, probably as part of a more general destruction of the glycocalyx. It is interesting, however, that disaccharidase levels were maintained in the upper and lower segments, in spite of the evidence that glycoprotein degradation was increased in these areas. These observations suggest that enhanced rates of enzyme synthesis were sufficient to compensate for losses in the less contaminated segments, but not in the mucosa of the SFBL. The fact that maltase activity was significantly higher in the lower segment brush borders from rats with SFBLs than in brush borders from the corresponding control segments suggests as well that synthetic rates may not be tightly coupled to local degradation rates, thus permitting overcompensation. The stimuli which couple synthetic rates to loss of membrane structures are presently unknown but could of course involve circulating and luminal factors emanating from distant sites such as the SFBL.

Experiments dealing with the turnover of intestinal proteins are complicated to some extent by the continuous and relatively rapid turnover of the intestinal cells themselves. Bacterial overgrowth might be expected to increase cell turnover (16), but this point has not been examined in the experimental blind loop syndrome where there is evidence of villus as well as crypt hypertrophy and therefore a longer migration path for the enterocyte. The most telling indications that cell turnover plays a relatively minor role in the rate of disaccharidase degradation in SFBL rats are the observations $(a)$ that alkaline phosphatase is preserved whereas enhanced cell turnover would be expected to affect all brush border enzymes to the same extent, and (b) that ${ }^{3} \mathrm{H}:{ }^{14} \mathrm{C}$ ratios are much higher in the brush border than in the homogenates of these rats, indicating that affected glycoproteins are predominantly from the brush border rather than from the total cell. 
Finally, it is of interest that lactase was the most severely affected of the three disaccharidases studied. Lactase also recovers more slowly in the blind loop during treatment with antibiotics (3). This enzyme seems to be most vulnerable in acute infections $(1,37)$, gluten-sensitive enteropathy (38), and malnutrition (39). The relative vulnerability of the disaccharidases in the experimental blind loop syndrome therefore appears to mimic that seen in human disease, and for that reason the experimental blind loop may provide an excellent model for future investigation of the pathogenesis of many types of secondary disaccharidase deficiency in man.

\section{ACKNOWLEDGMENTS}

The expert technical assistance of Mrs. Annie Madapallimattam is gratefully acknowledged.

This work was supported by the Medical Research Council of Canada.

\section{REFERENCES}

1. Coello-Ramirez, P., and F. Lifshitz. 1972. Enteric microflora and carbohydrate intolerance in infants with diarrhea. Pediatrics. 49: 233-242.

2. Bloch, R., M. Menge, M. Lorenz-Meyer, and E. O. Riecken. 1973. Morphologische und biochemische Veränderungen der Dünndarmschleimhaut beim Blindsack Syndrom. Verh. Dtsch. Ges. Inn. Med. 79: 853-856.

3. Giannella, R. A., W. R. Rout, and P. P. Toskes. 1974. Jejunal brush border injury and impaired sugar and amino-acid uptake in the blind loop syndrome. Gastroenterology. 67: 965-974.

4. Gracey, M., J. Thomas, and M. Houghton. 1975. Effect of stasis on intestinal enzyme activities. Aust. N. Z. J. Med. 5: $141-144$.

5. Nordstrom, C., A. Dahlqvist, and L. Josefsson. 1967. Quantitative determination of enzymes in different parts of the villi and crypts of rat small intestine. J. Histochem. Cytochem. 15: 713-721.

6. Drasar, B. S., M. J. Hill, and M. Shiner. 1966. The deconjugation of bile salts by human intestinal bacteria. Lancet. I: $1237-1238$.

7. Boedeker, E. C., Y. K. Higgins, R. M. Donaldson, and D. M. Small. 1976. Selective solubilization of enzyme proteins from microvillus membrane (MVM) using nonionic and anionic detergents. Gastroenterology. 70: 865. (Abstr.)

8. Gracey, M., M. Houghton, and J. Thomas. 1975. Deoxycholate depresses small intestinal enzyme activity. Gut. 16: 53-56.

9. Eichholz, A. 1968. Studies on the organization of the brush border in intestinal epithelial cells. V. Subfractionation of enzymatic activities of the microvillus membrane. Biochim. Biophys. Acta. 163: 101-107.

10. Alpers, D. H., and F. J. Tedesco. 1975. The possible role of pancreatic proteases in the turnover of intestinal brush border proteins. Biochim. Biophys. Acta. 401: 28-40.

11. Ament, M. E., S. Shinoda, D. Saunders, and C. Robin. 1972. Pathogenesis of steatorrhea in three cases of the small intestinal stasis syndrome. Gastroenterology. 63: 728.
12. Gracey, M., V. Burke, A. Oshin, J. Barker, and E. F. Glosgow. 1971. Bacteria, bile salts and intestinal monosaccharide malabsorption. Gut. 12: 683-692.

13. Gianella, R., P. Toskes, and W. Rout. 1973. Reversible brush border injury and impaired sugar and amino-acid uptake in the blind loop syndrome. Clin. Res. 21: 50.

14. Toskes, P. P., R. A. Giannella, H. R. Jervis, W. R. Rout, and A. Takeuchi. 1975. Small intestinal mucosal injury in the experimental blind loop syndrome: light- and electron-microscopic and histochemical studies. Gastroenterology. 68: 1193-1203.

15. Gracey, M., J. Papadimitriou, and G. Bower. 1974. Ultrastructural changes in the small intestines of rats with self-filling blind loop. Gastroenterology. 67: 646-651.

16. Abrams, G., H. Sauer, and H. Spring. 1963. Influence of normal flora on mucosal morphology and cellular renewal in the ileum. Lab. Invest. 12: 355-364.

17. Forstner, G. 1971. Release of intestinal surface membrane glycoproteins associated with enzyme activity by brief digestion with papain. Biochem. J. 121: 781-789.

18. Cameron, D. G., G. M. Watson, and L. J. Witts. 1949. Experimental production of macrocytic anemia by operations on the intestinal tract. Blood. 4: 803-815.

19. van der Kamer, J. H., H. Bokkel Hvinink, and H. A. Wejers. 1949. Rapid method for determination of fat in feces. J. Biol. Chem. 117: 347-355.

20. Hofmann, A. F. 1962. Thin layer chromatography of free and conjugated bile acids or silicic acid. J. Lipid Res. 3: $127-128$.

21. Sudarah, G. S., H. Singh, and H. S. Sodhi. 1971. Thin layer chromatographic separation of chemodeoxycholic and deoxycholic acids. Clin. Chem. Acta. 34: 425-429.

22. Kottke, B. A., J. Wollenweber, and C. A. Owen, Jr. 1966. Quantitative thin layer chromatography of free and conjugated cholic acid in human bile and duodenal content. J. Chromatogr. 21: 439-447.

23. Forstner, G., S. M. Sabesin, and K. J. Isselbacher. 1968. Rat intestinal microvillus membranes: purification and biochemical characterization. Biochem. J. 106: 381-390.

24. Dahlqvist, A. 1964. Method for assay of intestinal disaccharidases. Anal. Biochem. 7: 18-25.

25. Lowry, O. M., N. J. Rosenbrough, A. L. Farr, and R. J. Randall. 1951. Protein measurement with the Folin phenol reagent. J. Biol. Chem. 193: 265-275.

26. Allison, D. J., and Q. T. Smith. 1965. Application of a rapid and reliable method for determination of hexosamine in the skin of estrogen treated rats. Anal. Biochem. 13: 1965.

27. Chambers, R. E., and J. R. Clamp. 1971. An assessment of methanolysis and other factors used in the analysis of carbohydrate containing material. Biochem. J. 125: 1009-1017.

28. Forstner, G., and G. Galand. 1975. The influence of hydrocortisone on the synthesis and turnover of microvillous membrane glycoproteins in suckling rat intestine. Can. J. Biochem. 54: 224-232.

29. Galand, G., and G. Forstner. 1974. Isolation of microvillus plasma membranes from suckling-rat intestine: the influence of premature induction of digestive enzymes by injection of cortisol-acetate. Biochem. J. 144: 293-302.

30. Kelly, J. J., and D. H. Alpers. 1973. Properties of human intestinal glucoamylase. Biochim. Biophys. Acta. 315: 133-140.

31. Reddy, B. S., and B. D. Wostmann. 1966. Intestinal disaccharidase activities in the growing germfree and conventional rats. Arch. Biochem. Biophys. 113: 609-616. 
32. Prosper, J., R. L. Murray, and F. Kern. 1968. Protein starvation and the small intestine: disaccharidase activities. Gastroenterology. 55: 223-228.

33. Forstner, G. $1970 \cdot 1-{ }^{14} \mathrm{C}$ glucosamine incorporation by subcellular fractions of small intestinal mucosa. J. Biol. Chem. 245: 3584-3592.

34. Forstner, G. 1968. Incorporation of $1{ }^{-14} \mathrm{C}$ glucosamine by rat intestinal microvillus membrane. Biochim. Biophys. Acta. 150: 736-738.

35. Tabaqchali, S. 1970. The polyphysiological role of small intestinal bacterial flora. Scand. J. Gastroenterol. Suppl. 6: $139-163$.
36. Donaldson, R. 1967. Role of enteric micro-organisms in malabsorption. Fed. Proc. 26: 1426-1431.

37. Gray, G. M., W. M. Walter, and E. H. Colver. 1968. Persistent deficiency of intestinal lactase in apparently cured tropical sprue. Gastroenterology. 54: 552-558.

38. Welsh, J. D., O. M. Zschiesche, J. Anderson, and A. Walker. 1969. Intestinal disaccharidase activity in celiac sprue (gluten-sensitive enteropathy). Arch. Intern. Med. 123: $33-38$.

39. Prinsloo, J. G., W. Wittmann, P. J. Pretorius, H. Kruger, and S. A. Fellingham. 1969. Effect of different sugars on diarrhoea of acute Kwashiorkor. Arch. Dis. Child. 44: 593-599. 